\title{
Analysis of the Effect of Prices, Promotions and Products on Purchase Interest Impacts on Consumer Satisfaction of VIVO Brand Mobile Phones in South Tangerang Region
}

\author{
Jasmani $^{1}$, Sutiman ${ }^{2}$, Denok Sunarsi ${ }^{3}$ \\ 1,2,3 Universitas Pamulang \\ E-mail: dosen01770@unpam.ac.id
}

\begin{abstract}
Vivo, one of the brand new handphone brands, entered Indonesia in 2014. Not just trying to exist in the smartphone industry, but Vivo also has the ambition to become a new giant force in the world. This study aims to determine the effect of prices, promotions and products on buying interest that has an impact on consumer satisfaction VIVO brand mobile phones in the South Tangerang area. The method used was explanatory research with a sample of 96 respondents. The analysis technique uses instrument testing, classical assumption test, regression testing, correlation coefficient, coefficient of determination and hypothesis testing. The results of this study significantly influence the price of buying interest by $25.4 \%$, the hypothesis test obtained significance $0,000<0.05$. Promotion has a significant effect on buying interest by $40.2 \%$, hypothesis testing is obtained significance of $0,000<0.05$. The product has a significant effect on buying interest of $23.8 \%$, the hypothesis test obtained a significance of $0,000<0.05$. Price, promotion and product simultaneously had a significant effect on buying interest of $49.3 \%$, the hypothesis test obtained a significance of $0,000<0.05$. Purchasing interest has a significant effect on customer satisfaction by $48.5 \%$, the hypothesis test is obtained significance of $0,000<0.05$. Towards consumer satisfaction of $45.5 \%$, the hypothesis test is obtained significance of $0,000<0.05$.
\end{abstract}

Keywords: Price, promotion; product; buying interest; customer satisfaction.

\section{INTRODUCTION}

The domestic telecommunications and information industry (telematics) experienced significant growth after the implementation of the domestic component-level policy (TKDN) for smartphones and 4G information technology devices (De Haes \& Van Grembergen, 2009; Iyengar et al., 2020; Pack \& Todaro, 1969; Shamdasani et al., 2008; Venkatesh et al., 2003; Yu et al., 2020). Telematics products provide extraordinary market space in Indonesia, this can be seen from smartphone sales of up to 60 million units per year. Meanwhile, until 2016, there were 23 electronics manufacturing services (EMS), 42 brands and 37 brand owners both global and national, with a total investment of Rp. 7 trillion. The technology cycle is very fast, especially smart phones, which every six months there are always the latest product updates, so it requires the power of research and technological innovation (Rengifurwarin et al., 2018; Syam et al., 2018). (Ali et al., 2020; Heikkinen et al., 2020; Srinivas et al., 2019; Wen et al., 2020; Yang, 2015) In addition to the growth of the hardware industry, currently the government is also encouraging the development of the software, content and animation industries. For this reason, the Ministry of Industry has issued Regulation of the Minister of Industry No. 65 of 


\section{Jurnal Administrare: Jurnal Pemikiran Ilmiah dan Pendidikan Administrasi Perkantoran Vol. 7, No. 1, January - June 2020, Pages 73-82}

2016 concerning the provisions and procedures for calculating the value of domestic component levels of cellular telephone products, handheld computers, and tablet computers.

Cellphone (smartphone) users in the country reached 371.4 million users or 142 percent of the total population of 262 million people. That is, on average each resident uses 1.4 cell phones because one person sometimes uses 2-3 cell phone cards. While Indonesia's urban population reaches 55 percent of the total population. Compared to the position in January 2016, Indonesian smartphone users increased 14 percent. As for penetration using active social media increased 34 percent, and penetration of active mobile social media users increased by 39 percent. It is undeniable that in Indonesia there are more and more smartphone users. Do not look at class, job, salary, etc. Just look around us, even my friend once told me that scavengers now have smartphones. Even without data, it can be seen roughly how much smartphone penetration is in Indonesia

Not only does it show consistency to continue to present surprises in its journey in the midst of competitive markets, the full range of breakthrough technologies that Vivo presents contributes to making it one of the pioneering brands forming global industry trends to date. In 2018, Vivo used the Mobile World Congress (MWC) title to introduce the revolutionary APEX concept smartphone with a screen ratio of up to $90 \%$. This Vivo prototype has a 5.99 inch OLED screen with COF technology. For the size of the side bezel is quite thin only $1.8 \mathrm{~mm}$ while at the bottom $4.3 \mathrm{~mm}$.

\section{METHOD}

The type of research used is associative, where the aim is to determine the relationship between variables (Creswell, 2013; Creswell \& Creswell, 2017). The population in this study amounted to 96 respondents VIVO brand mobile users in the South Tangerang Region . The sampling technique in this study is saturated sampling, where all members of the population are sampled. Thus the sample in this study amounted to 96 respondents. VIVO brand cell phone users in the South Tangerang Region are not known with certainty, therefore the author uses the Rao Purba formula and obtained a sample of 96 respondents. In analyzing the data used instrument test, classical assumption test, regression, coefficient of determination and hypothesis testing(Creswell \& Creswell, 2017).

\section{RESULT AND DISCUSSION}

Vivo, one of the brand new handphone brands, entered Indonesia in 2014. Not just trying to exist in the smartphone industry, but Vivo also has the ambition to become a new giant force in the world, at the 2018 World Cup, the Vivo brand was always present in every month for every month. Vivo is everywhere, both in stadiums in Russia, to screens throughout the world. Vivo clearly wants to be better known to the world community. The action will at least not stop until the next few years. The reason is, Vivo also sponsors the FIFA World Cup until the upcoming 2022 World Cup. 


\section{Descriptive Analysis}

In this test used to determine the highest minimum and maximum scores, ratting scores and standard deviations of each variable. The results are as follows:

Table 1

Statistical Descriptive Analysis Results

Descriptive Statistics

\begin{tabular}{l|r|r|r|r|r}
\hline & N & Minimum & Maximum & The mean & Std. Deviation \\
\hline Price (X1) & 96 & 29 & 46 & 37.41 & 3,718 \\
\hline Promotion (X2) & 96 & 31 & 46 & 38.08 & 3,364 \\
\hline Products (X3) & 96 & 30 & 46 & 37.99 & 3,848 \\
\hline Purchase Interest (Y) & 96 & 32 & 46 & 39.00 & 3,446 \\
\hline Consumer Satisfaction (Z) & 96 & 32 & 45 & 39.74 & 3,245 \\
\hline Valid N (listwise) & 96 & & & & \\
\hline
\end{tabular}

Prices obtained a minimum variance of 29 and a maximum variance of 46 with a ratting score of 3.741 with a standard deviation of 3.718. Promotion obtained a minimum variance of 31 and a maximum variance of 46 with a ratting score of 3.808 with a standard deviation of 3.364. The product obtained a minimum variance of 30 and a maximum variance of 46 with a ratting score of 3.799 with a standard deviation of 3.848. Purchase interest is obtained a minimum variance of 32 and a maximum variance of 46 with a ratting score of 3,900 with a standard deviation of 3,446. Consumer satisfaction obtained a minimum variance of 32 and a maximum variance of 45 with a ratting score of 3.974 with a standard deviation of 3.245.

\section{Multiple Regression Analysis}

This regression test is intended to determine changes in the dependent variable if the independent variable changes. The test results are as follows:

Table 2

Multiple Regression Testing Results

Coefficients $^{\text {a }}$

\begin{tabular}{|c|c|c|c|c|c|c|}
\hline \multirow{2}{*}{\multicolumn{2}{|c|}{ Model }} & \multicolumn{2}{|c|}{$\begin{array}{l}\text { Unstandardized } \\
\text { Coefficients }\end{array}$} & \multirow{2}{*}{$\begin{array}{c}\text { Standardized } \\
\text { Coefficients } \\
\text { Beta } \\
\end{array}$} & \multirow[b]{2}{*}{$\mathrm{t}$} & \multirow[b]{2}{*}{ Sig. } \\
\hline & & B & Std. Error & & & \\
\hline & (Constant) & 6,957 & 3,416 & & 2,037 & .045 \\
\hline & Price (X1) & .226 & .078 & .243 & 2,895 & .005 \\
\hline & Promotion (X2) & .444 & .91 & .434 & 4,863 & .000 \\
\hline & Products (X3) & .176 & .077 & .196 & 2,292 & .024 \\
\hline
\end{tabular}

a. Dependent Variable: Purchase Interest (Y) 
Based on the test results in the above table, the regression equation $\mathrm{Y}=6.957+0.226 \mathrm{X} 1$ $+0.444 \mathrm{X} 2+0.176 \mathrm{X} 3$ is obtained. A constant of 6.957 means that if there is no price and promotion, then there is a value of buying interest of 6.957 points. Price regression coefficient of 0.226 , this number is positive meaning that every time there is an increase in price of 0.226 , buying interest will also increase by 0.226 points. Promotion regression coefficient of 0.444 , this number is positive, meaning that every time there is an increase in promotion of 0.444 , buying interest will also increase by 0.444 points. Product regression coefficient of 0.176 , this number is positive meaning that every time there is an increase in products by 0.176 , buying interest will also increase by 0.176 points.

\section{Correlation Coefficient Analysis}

Correlation coefficient analysis is intended to determine the degree of relationship strength of the independent variables on the dependent variable either partially or simultaneously. The test results are as follows:

\section{Table 3}

\section{Test Results The Price Correlation Coefficient of Buying Interest.}

\section{Correlations $^{b}$}

\begin{tabular}{llr|r}
\hline & & Price $(\mathrm{X} 1)$ & Purchase Interest (Y) \\
\hline Price (X1) & Pearson Correlation & 1 & $.504^{* *}$ \\
\cline { 2 - 4 } & Sig. (2-tailed) & & .000 \\
\hline Purchase Interest (Y) & Pearson Correlation & $.504^{* *}$ & 1 \\
\cline { 2 - 4 } & Sig. (2-tailed) & .000 & \\
\hline
\end{tabular}

**. Correlation is significant at the 0.01 level (2-tailed).

b. Listwise $\mathrm{N}=96$

Based on the test results obtained by the correlation value of 0.504 means that the price has a moderate relationship with buying interest.

\section{Table 4 .}

Test Results Correlation Coefficient Promotion Promotion of Purchase Interest.

\section{Correlations $^{\text {b }}$}

\begin{tabular}{llr|r}
\hline & & $\begin{array}{c}\text { Promotion } \\
(\mathrm{X} 2)\end{array}$ & $\begin{array}{r}\text { Purchase Interest (Y) } \\
\hline \text { Promotion (X2) }\end{array}$ \\
\cline { 2 - 4 } & Pearson Correlation & 1 & $.634^{* *}$ \\
\cline { 2 - 4 } Purchase Interest (Y) (2-tailed) & Pearson Correlation & $.634^{* *}$ & .000 \\
\cline { 2 - 4 } & Sig. (2-tailed) & .000 & 1 \\
\hline
\end{tabular}

**. Correlation is significant at the 0.01 level (2-tailed).

b. Listwise $\mathrm{N}=96$

Based on the test results obtained a correlation value of 0.634 means that promotion has a strong relationship with buying interest. 


\section{Table 5}

Product Correlation Coefficient Testing Results to Purchase Interest.

\begin{tabular}{llr|r}
\hline \multicolumn{4}{c}{ Correlations $^{\mathbf{b}}$} \\
\hline & \multicolumn{2}{c}{ Products (X3) } & Purchase Interest (Y) \\
\hline Products (X3) & Pearson Correlation & 1 & $.487^{* *}$ \\
\cline { 2 - 4 } & Sig. (2-tailed) & & .000 \\
\hline Purchase Interest (Y) & Pearson Correlation & $.487^{* *}$ & 1 \\
\cline { 2 - 4 } & Sig. (2-tailed) & .000 & \\
\hline
\end{tabular}

**. Correlation is significant at the 0.01 level (2-tailed).

b. Listwise $\mathrm{N}=96$

Based on the test results obtained by a correlation value of 0.487 means that the product has a moderate relationship with buying interest.

\section{Table 6}

Simultaneous Correlation Test Results Prices, Products and Promotions to Purchase Interest.

\section{Summary Model}

\begin{tabular}{lrr|r|r}
\hline Model & R & R Square & Adjusted R Square & $\begin{array}{c}\text { Std. Error of the } \\
\text { Estimate }\end{array}$ \\
\hline 1 & $702^{\mathrm{a}}$ & .493 & .477 & 2,493 \\
\hline
\end{tabular}

a. Predictors: (Constant), Products (X3), Prices (X1), Promotions (X2)

Based on the test results obtained by the correlation value of 0.702 means that prices, promotions and products simultaneously have a strong relationship to buying interest.

\section{Table 7}

Test Results Correlation coefficient of Purchase Interests to Consumer Satisfaction.

\section{Correlations $^{\mathrm{b}}$}

\begin{tabular}{llr|r}
\hline & & \multicolumn{1}{c}{$\begin{array}{c}\text { Purchase } \\
\text { Interest (Y) }\end{array}$} & \multicolumn{1}{c}{$\begin{array}{c}\text { Consumer } \\
\text { Satisfaction (Z) }\end{array}$} \\
\hline Purchase Interest (Y) & Pearson Correlation & 1 & $.697^{* * *}$ \\
\cline { 2 - 4 } & Sig. (2-tailed) & & .000 \\
\hline Consumer Satisfaction (Z) & Pearson Correlation & $.697^{* *}$ & 1 \\
\cline { 2 - 4 } & Sig. (2-tailed) & .000 & \\
\hline **. Correlation is significant at the 0.01 level (2-tailed). & & \\
b. Listwise N = 96
\end{tabular}

Based on the test results obtained by a correlation value of 0.697 means that buying interest has a strong relationship with customer satisfaction. 
78 Jurnal Administrare: Jurnal Pemikiran Ilmiah dan Pendidikan Administrasi Perkantoran Vol. 7, No. 1, January - June 2020, Pages 73-82

\section{Analysis of the Coefficient of Determination}

Analysis of the coefficient of determination is intended to determine the percentage of influence of the independent variable on the dependent variable either partially or simultaneously. The test results are as follows:

Table 8

Test Results The Price Determination Coefficient of Buying Interest.

Summary Model

\begin{tabular}{|c|c|c|c|c|}
\hline Model & $\mathrm{R}$ & R Square & $\begin{array}{l}\text { Adjusted R } \\
\text { Square }\end{array}$ & $\begin{array}{l}\text { Std. Error of the } \\
\text { Estimate }\end{array}$ \\
\hline 1 & $.504^{\mathrm{a}}$ & .254 & .246 & 2,993 \\
\hline
\end{tabular}

a. Predictors: (Constant), Price (X1)

Based on the test results obtained a coefficient of determination of 0.254 means that the price has an influence contribution of $25.4 \%$ on buying interest.

Table 9

Test Results for Promotion Determination Coefficient on Buying Interest.

Summary Model

\begin{tabular}{|c|c|c|c|c|}
\hline Model & $\mathrm{R}$ & R Square & $\begin{array}{l}\text { Adjusted R } \\
\text { Square }\end{array}$ & $\begin{array}{l}\text { Std. Error of the } \\
\text { Estimate }\end{array}$ \\
\hline . & $.634^{\mathrm{a}}$ & .402 & .395 & 2,680 \\
\hline
\end{tabular}

a. Predictors: (Constant), Promotion (X2)

Based on the test results obtained a coefficient of determination of 0.402 means that the promotion has an influence contribution of $40.2 \%$ on buying interest.

Table 10

Test Results for Price, Promotion and Product Determination Coefficients of Buying Interest.

Summary Model

\begin{tabular}{|c|c|c|c|c|}
\hline Model & $\mathrm{R}$ & R Square & $\begin{array}{l}\text { Adjusted R } \\
\text { Square }\end{array}$ & $\begin{array}{l}\text { Std. Error of the } \\
\text { Estimate }\end{array}$ \\
\hline 1 & $.487^{\mathrm{a}}$ & .238 & .229 & 3,025 \\
\hline
\end{tabular}

a. Predictors: (Constant), Products (X3)

Based on the test results obtained a coefficient of determination of 0.238 means that the product has an influence contribution of $23.8 \%$ on buying interest. 
Table 11.

Testing Results Coefficient of Determination Price, Promotion and Product $t$ erhadap Interests Buy.

Summary Model

\begin{tabular}{lrr|rrr}
\hline Model & & \multicolumn{2}{c|}{$\begin{array}{c}\text { Adjusted R } \\
\text { Square }\end{array}$} & $\begin{array}{c}\text { Std. Error of the } \\
\text { Estimate }\end{array}$ \\
\hline 1 & $\mathrm{R}$ & \multicolumn{1}{c|}{ R Square } & .493 & .477 & 2,493 \\
\hline
\end{tabular}

a. Predictors: (Constant), Products (X3), Prices (X1), Promotions (X2)

Based on the test results obtained a coefficient of determination of 0.493 means that simultaneous price, promotion and product have an influence contribution of $49.3 \%$ to buying interest, while the remaining $50.7 \%$ is influenced by other factors.

Table 12

Test Results for the Determination of Buy Interest Coefficient on Consumer Satisfaction.

Summary Model

\begin{tabular}{|c|c|c|c|c|}
\hline Model & $\mathrm{R}$ & R Square & $\begin{array}{l}\text { Adjusted R } \\
\text { Square }\end{array}$ & $\begin{array}{l}\text { Std. Error of the } \\
\text { Estimate }\end{array}$ \\
\hline 1 & $.697^{\mathrm{a}}$ & .485 & .480 & 2,341 \\
\hline
\end{tabular}

a. Predictors: (Constant), Purchase Interest (Y)

Based on the test results obtained a coefficient of determination of 0.485 means that buying interest has a contribution of $48.5 \%$ on consumer satisfaction.

\section{Hypothesis testing}

Hypothesis testing with $\mathrm{t}$ test is used to find out which partial hypotheses are accepted.

Table 13

Price Hypothesis Test Results to Purchase Interest.

Coefficients a

\begin{tabular}{|c|c|c|c|c|c|c|}
\hline \multirow{2}{*}{\multicolumn{2}{|c|}{ Model }} & \multicolumn{2}{|c|}{ Unstandardized Coefficients } & \multirow{2}{*}{$\begin{array}{c}\text { Standardized } \\
\text { Coefficients } \\
\text { Beta } \\
\end{array}$} & \multirow[b]{2}{*}{$\mathrm{t}$} & \multirow[b]{2}{*}{ Sig. } \\
\hline & & B & Std. Error & & & \\
\hline 1 & (Constant) & 21,538 & 3,104 & & 6,938 & .000 \\
\hline & Price $(\mathrm{X} 1)$ & .467 & .083 & .504 & 5,653 & .000 \\
\hline
\end{tabular}

a. Dependent Variable: Purchase Interest (Y)

Based on the results of tests on $t$ abel above, the value of $t$ count $>t$ table or (5.653>1.986), thus the hypothesis that there is a significant influence on the price of buying interest atara accepted. 
80 Jurnal Administrare: Jurnal Pemikiran Ilmiah dan Pendidikan Administrasi Perkantoran Vol. 7, No. 1, January - June 2020, Pages 73-82

Table 14

Promotion Hypothesis Test Results for Buy Interest.

Coefficients $^{\text {a }}$

\begin{tabular}{|c|c|c|c|c|c|c|}
\hline \multirow{2}{*}{\multicolumn{2}{|c|}{ Model }} & \multicolumn{2}{|c|}{$\begin{array}{c}\text { Unstandardized } \\
\text { Coefficients }\end{array}$} & \multirow{2}{*}{$\begin{array}{l}\text { Standardized } \\
\text { Coefficients } \\
\text { Beta }\end{array}$} & \multirow[b]{2}{*}{$\mathrm{t}$} & \multirow[b]{2}{*}{ Sig. } \\
\hline & & B & Std. Error & & & \\
\hline \multirow[t]{2}{*}{1} & (Constant) & 14,280 & 3,124 & & 4,571 & .000 \\
\hline & Promotion (X2) & 649 & .082 & .634 & 7,944 & .000 \\
\hline
\end{tabular}

a. Dependent Variable: Purchase Interest (Y)

Based on the test results in the above table, the value of $t_{\text {count }}>t_{\text {table }}$ or $(7.944>1.986)$ is obtained, thus the hypothesis that there is a significant influence on promotion of buying interest is accepted.

Table 15

Product Hypothesis Test Results to Purchase Interest.

Coefficients a

\begin{tabular}{|c|c|c|c|c|c|c|}
\hline \multirow{2}{*}{\multicolumn{2}{|c|}{ Model }} & \multicolumn{2}{|c|}{$\begin{array}{c}\text { Unstandardized } \\
\text { Coefficients }\end{array}$} & \multirow{2}{*}{$\begin{array}{l}\text { Standardized } \\
\text { Coefficients } \\
\text { Beta }\end{array}$} & \multirow[b]{2}{*}{$\mathrm{t}$} & \multirow[b]{2}{*}{ Sig. } \\
\hline & & $\mathrm{B}$ & Std. Error & & & \\
\hline \multirow[t]{2}{*}{1} & (Constant) & 22,422 & 3,079 & & 7,282 & .000 \\
\hline & Products (X3) & .436 & .081 & .487 & 5.412 & .000 \\
\hline
\end{tabular}

a. Dependent Variable: Purchase Interest (Y)

Based on the test results in the above table, the value of $t_{\text {count }}>t$ table or (5.412>1.986) is obtained, thus the hypothesis proposed that there is a significant influence between the products on buying interest is accepted.

Table 16 .

Hypothesis Test Results of Purchase Interest on Consumer Satisfaction. Coefficients ${ }^{\text {a }}$

\begin{tabular}{|c|c|c|c|c|c|c|}
\hline \multirow{2}{*}{\multicolumn{2}{|c|}{ Model }} & \multicolumn{2}{|c|}{ Unstandardized Coefficients } & \multirow{2}{*}{$\begin{array}{c}\text { Standardized } \\
\text { Coefficients } \\
\text { Beta }\end{array}$} & \multirow[b]{2}{*}{$\mathrm{t}$} & \multirow[b]{2}{*}{ Sig. } \\
\hline & & B & Std. Error & & & \\
\hline \multirow[t]{2}{*}{1} & (Constant) & 14,154 & 2,729 & & 5,188 & .000 \\
\hline & $\begin{array}{l}\text { Purchase Interest } \\
\text { (Y) }\end{array}$ & .656 & .070 & .697 & 9,413 & .000 \\
\hline
\end{tabular}

a. Dependent Variable: Consumer Satisfaction (Z)

Based on the test results in the above table, the value of $t_{\text {count }}>t$ table or $(9.413>1.986)$ is obtained, thus the hypothesis proposed that there is a significant influence between the products on buying interest is accepted. 
Jasmani, Sutiman, Denok Sunarsi; Analysis of the Effect of Prices, Promotions and Products ...|81

Hypothesis testing with the F test is used to find out which simultaneous hypotheses are accepted.

Table 17

Price, Promotion and Product Hypothesis Test Results to Purchase Interest.

\begin{tabular}{llr|r|r|r|r}
\multicolumn{7}{c}{ ANOVA $^{\text {a }}$} \\
\hline \multicolumn{1}{l}{ Model } & Sum of Squares & \multicolumn{1}{c}{ df } & Mean Square & F & \multicolumn{1}{c}{ Sig. } \\
\hline \multirow{2}{*}{1} & Regression & 556,444 & 3 & 185,481 & 29,856 & $.000^{\mathrm{b}}$ \\
\cline { 2 - 8 } & Residual & 571,556 & 92 & 6.213 & & \\
\cline { 2 - 8 } & Total & 1128,000 & 95 & & & \\
\hline
\end{tabular}

a. Dependent Variable: Purchase Interest (Y)

b. Predictors: (Constant), Products (X3), Prices (X1), Promotions (X2)

Based on the test results in the above table, the value of $F_{\text {count }}>F_{\text {table }}$ or $(29.885>2,700)$ is obtained, thus there is a significant influence between price, promotion and product simultaneously on buying interest.

\section{CONCLUSION}

Based on the results $h$ arga significant effect on buying interest by contributing effect of $25.4 \%$. Hypothesis test obtained by value $\mathrm{t}_{\text {count }}>\mathrm{t}$ table or $(5.653>1.986)$. Promotion has a significant effect on buying interest with a contribution of $40.2 \%$. Hypothesis test obtained by value $t_{\text {coum }}>t_{\text {tabl }}$ or $(7.944>1.986)$. The product has a significant effect on buying interest with a contribution of $23.8 \%$. Hypothesis testing obtained $t_{\text {count }}>t_{\text {able }}$ or $(5.412>1.986)$. Price, promotion and product have a significant effect on buying interest with a contribution of $49.3 \%$ while the remaining $50.7 \%$ is influenced by other factors. Hypothesis testing obtained by catulating the value of $\mathrm{F}$ $>\mathrm{F}_{\text {thb }}$ or (29.885> 2.700). Purchasing interest has a significant effect on customer satisfaction with a contribution of $48.5 \%$. Hypothesis testing obtained $t$ count $>t$ table or $(9.413>1.986)$.

\section{REFERENCES}

Ali, O., Shrestha, A., Chatfield, A., \& Murray, P. (2020). Assessing information security risks in the cloud: A case study of Australian local government authorities. Government $\begin{array}{lll}\text { Information } & \text { Quarterly, } & 101419 .\end{array}$ https://doi.org/https://doi.org/10.1016/j.giq.2019.101419

Creswell, J. W. (2013). Research Design: Qualitative Approach, Quantitative and Mixed. Yogyakarta: Student Library.

Creswell, J. W., \& Creswell, J. D. (2017). Research design: Qualitative, quantitative, and mixed methods approaches. Sage publications.

De Haes, S., \& Van Grembergen, W. (2009). Enterprise Governance of Information Technology. In Enterprise Governance of Information Technology. https://doi.org/10.1007/978-0-387-84882-2

Heikkinen, I. T. S., Savin, H., Partanen, J., Seppälä, J., \& Pearce, J. M. (2020). Towards 


\section{Jurnal Administrare: Jurnal Pemikiran Ilmiah dan Pendidikan Administrasi Perkantoran}

Vol. 7, No. 1, January - June 2020, Pages 73-82

national policy for open source hardware research: The case of Finland. Technological $\begin{array}{lllll}\text { Forecasting } & \text { Shd }\end{array}$ https://doi.org/https://doi.org/10.1016/j.techfore.2020.119986

Iyengar, K., Upadhyaya, G. K., Vaishya, R., \& Jain, V. (2020). COVID-19 and applications of smartphone technology in the current pandemic. Diabetes \& Metabolic Syndrome: Clinical Research \& Reviews, 14(5), 733-737. https://doi.org/https://doi.org/10.1016/j.dsx.2020.05.033

Pack, H., \& Todaro, M. (1969). Technological transfer, labour absorption, and economic development. Oxford Economic Papers, 21(3), 395-403.

Rengifurwarin, Z. A., Akib, H., \& Salam, R. (2018). Snapshot of public service quality in the center for integrated business service (CIBS), cooperative micro small and medium enterprises (CMSME), Maluku Province, Indonesia. Journal of Entrepreneurship Education.

Shamdasani, P., Mukherjee, A., \& Malhotra, N. (2008). Antecedents and consequences of service quality in consumer evaluation of self-service internet technologies. Service Industries Journal, 28(1), 117-138. https://doi.org/10.1080/02642060701725669

Srinivas, J., Das, A. K., \& Kumar, N. (2019). Government regulations in cyber security: Framework, standards and recommendations. Future Generation Computer Systems, 92, 178-188. https://doi.org/https://doi.org/10.1016/j.future.2018.09.063

Syam, H., Akib, H., Patonangi, A. A., \& Guntur, M. (2018). Principal Entrepreneurship Competence Based on Creativity and Innovation in the Context of Learning Organizations in Indonesia. Journal of Entrepreneurship Education, 21(3), 1-13.

Venkatesh, V., Morris, M. G., Davis, G. B., \& Davis, F. D. (2003). User acceptance of information technology: Toward a unified view. MIS Quarterly, 27(3), 25-478. https://doi.org/10.2307/30036540

Wen, M., Siqueira, R., Lago, N., Camarinha, D., Terceiro, A., Kon, F., \& Meirelles, P. (2020). Leading successful government-academia collaborations using FLOSS and agile values. $\begin{array}{lllll}\text { Journal of Systems and Software, } & 164, & 10548 .\end{array}$ https://doi.org/https://doi.org/10.1016/j.jss.2020.110548

Yang, R. J. (2015). Overcoming technical barriers and risks in the application of building integrated photovoltaics (BIPV): hardware and software strategies. Automation in Construction, 51, 92-102. https://doi.org/https://doi.org/10.1016/j.autcon.2014.12.005

Yu, G., Tang, Z., Chen, H., Chen, Z., Wang, L., Cao, H., Wang, G., Xing, J., Shen, H., Cheng, Q., Li, D., Wang, G., Xiang, Y., Guan, Y., Zhu, Y., Liu, Z., \& Bai, Z. (2020). Long-term exposure to $4 \mathrm{G}$ smartphone radiofrequency electromagnetic radiation diminished male reproductive potential by directly disrupting Spock3-MMP2-BTB axis in the testes of adult rats. Science of The Total Environment, 698, 133860. https://doi.org/https://doi.org/10.1016/j.scitotenv.2019.133860 